\title{
Frequency and Associated Factors of Home Injuries in Pre-school Children over 3 Years of Age
}

\author{
(1) Ersin Uskun¹, (1) Serdar Yıldırım², (1) Mustafa Volkan Yürekli1, (1) Ayşe Çelik³, (1) Yasemin Tarcan4
}

1Süleyman Demirel University Faculty of Medicine, Department of Public Health, Isparta, Turkey

2Isparta Community Health Center, Isparta, Turkey

${ }^{3}$ Eğirdir District Health Directorate, Isparta, Turkey

${ }^{4}$ Süleyman Demirel University, Isparta Health Services Vocational School, Isparta, Turkey

\begin{abstract}
Aim: The home injury risk of children is high because of a lack of awareness to danger, a sensitivity to environmental risks and curiosity about finding and learning new things. The main aims of this study were to determine the frequency of home injuries in children over 3 years of age; to examine the relationship between the frequency of home injuries and the characteristics of the home and the safety measures taken.

Materials and Methods: The study data were collected through a questionnaire on socio-demographic characteristics, safety of the home and the "Scale for Identification by Mothers of the Safety Measures Taken to Prevent Home Injuries in Children between 0-6 Ages".

Results: In this study, it was determined that $26.4 \%$ of children had had a home injury at least once in their life, and $7.3 \%$ of the children had had a home injury during the previous year. The most common home injury was falling and the most frequently injured area was the upper and/ or lower extremity. It was determined that the injuries occurred most frequently in the lounge, in summer, on Tuesdays, and in the afternoon.

Conclusion: Supervision of children is very important in terms of preventing possible injuries. It should not be forgotten that home injuries are preventable. Parents should be educated with regards to home injuries.
\end{abstract}

Keywords: Home injuries, injuries, frequency, playschool, play age child

\section{Introduction}

An accident is an unplanned, unexpected, sudden occurrence of injury, damage, or loss of person/property that can be avoided (1). According to the World Health Organization, an accident is defined as "an unexpected event that leads to physical and mental impairment that occurs suddenly" (2). An injury that happens in a house or in the surrounding area is called a home injury. In other words, home injuries are injuries that occur in the living room, kitchen, bedroom, balcony, garden, garages, etc. Home injuries are considered to be an important public health problem as they can lead to injury, disability and death (3). Children have a high risk of home injuries due to a lack of awareness of hazards, sensitivity to environmental risks, and a curiosity about finding and learning. Especially in the pre-school period, children who are at home are more susceptible to home injuries. Injuries affect the health of the child by acting physically, psychologically and socially, causing disorder, illness, disability and even death. Although there is no definite number for home injuries in Turkey, according to research, it has been determined that $18-25 \%$ of all injuries are caused by home injuries. In our country, the ratio of home injuries in children between 0-6 years old was reported to be $38 \%$ (4) and it was found that $50-80 \%$ 
of falling events in the same age group resulted in death (5). Injuries which are the result of misbehaviour or negligence are preventable by precautionary measures.

The purpose of this study was to determine the frequency of home injuries seen in children over 3 years of age who were attending kindergartens attached to the Directorate of National Education located in a provincial centre and to investigate the home-related characteristics of these injuries and any relationships between parental safety measures and home injuries.

\section{Materials and Methods}

This cross-sectional study was conducted at a provincial centre in the Mediterranean Region. The study sample included children over 3 years of age who were attending all kindergartens attached to the Directorate of National Education in the province centre $(n=1,399)$. It was planned to reach the entire universe without sampling but only 1,240 children were included due to reasons such as absenteeism, not knowing Turkish, not accepting the questionnaire, etc. (88.6\%). Data were collected by means of a questionnaire on the socio-demographic characteristics of children and the safety of the house in terms of home injuries, "The Scale for 0-6 age group of children in order to detect Security Measures Against Homicide" and by face-to-face interviews with their mothers. Çınar and Görak (6) developed a scale in order to recognize the measures to be taken by the mothers of children between the ages of 0-6 years for the protection of their children against home injuries. This scale is Likerttype 5 and includes a total of 40 items among which 34 were positive and 6 were negative. In this scale, answers are given in the form of always, often, sometimes, rarely or never. Among the responses to positive statements; always was assessed as 5 points, often as 4 points, sometimes as 3 points, rarely as 2 points and never as 1 point. Among the responses to negative statements; always was assessed as 5 points, often as 4 points, sometimes as 3 points, rarely as 2 points and never as 1 point. Scores were calculated by adding the points from each item of the scale. The lowest score that can be obtained from the scale is 40 , and the highest score is 200. A high score indicates that the mothers displayed positive behaviour in taking security measures against home injuries. The Cronbach's alpha coefficient was reported to be 0.82 , and was calculated to be 0.87 in this study.

All accidents, injuries and characteristics were classified using the International Classification of Diseases-10 diagnostic code system (7).
A 20-item checklist which identifies security measures to be taken at home was prepared and the number of security measures implemented/identified at home was determined. The minimum number of security measures that can be taken is 0 , and the highest number of security measures is 20 .

The dependent variable of research was the condition of child who had had a home injury in the past year; and independent variables were; age, gender, having a chronic illness, the presence of a person in need of special care at home, income status, mother's age, mother's educational status, mother's occupation, father's age, father's educational status, father's occupation, type of house, type of home heating system and the security measure scale points. Data were evaluated using descriptive statistics, t-test and chi-square analysis via the SPSS version 15.0 package program.

In univariate analysis, variables that were significantly related to home-related injuries (having chronic illness, low income, number of home-based measures) and the safety measure diagnostic score (not significant) were included in the logistic regression model. The analysis was performed by the backward-LR method. The model fit was assessed by the Hosmer-Lemeshow test and as the test result was $p>0.05$ ( $p=0.672)$, it was determined that the model had a high predictive value.

Required permissions for the study was obtained from the Ethics Committee of the Süleyman Demirel University Faculty of Medicine (Decision no: 200).

\section{Results}

In our study group, $50.4 \%$ were male, the average age was $55.8 \pm 9.0$ months (Table I). $92.1 \%$ of the children's families were nuclear families and $8.2 \%$ of children's families had low income. The mean age of the children's parents was $33.1 \pm 5.0$ years (mothers) and $36.3 \pm 5.4$ years (fathers). $51.0 \%$ of the parents and $60.0 \%$ of the fathers had graduated from university. $40.7 \%$ of the parents and $1.7 \%$ of the fathers were not working. $81.5 \%$ of the houses in which the children live were apartments (Table II). $26.4 \%$ of the children had had a home injury at some point in their life and $7.3 \%$ of them had a home injury within the previous year. Within the previous year, the two most common types of home injuries resulted from falling from rest/armchair/furniture/tree $(25.3 \%)$ or collision with objects (19.2\%). The most commonly injured area of the body was the upper and/or lower extremity (53.5\%). The most common cause of injury was household items/blunt 


\begin{tabular}{|c|c|c|c|c|}
\hline \multirow{2}{*}{ Characteristics } & \multirow{2}{*}{ Total $^{\mathrm{a}}$} & \multicolumn{2}{|c|}{ Home injury occurance } & \multirow{2}{*}{ p-value } \\
\hline & & Positive & Negative & \\
\hline Age of children [Mean $( \pm S D)]$ & $55.8( \pm 9.0)$ & $54.7( \pm 10.3)$ & $55.9( \pm 8.9)$ & 0.003 \\
\hline \multicolumn{4}{|l|}{ Gender [n (\%)] } & \multirow{3}{*}{0.462} \\
\hline Male & $615(49.6)$ & $48(7.8)$ & $567(92.2)$ & \\
\hline Female & $625(50.4)$ & $42(6.7)$ & $583(93.3)$ & \\
\hline Number of siblings [Mean $( \pm S D)]$ & $0.9( \pm 0.8)$ & $1.0( \pm 0.8)$ & $0.9( \pm 0.7)$ & 0.502 \\
\hline \multicolumn{4}{|l|}{ In which order [n (\%)] } & \multirow{4}{*}{0.429} \\
\hline First-single & 833 & $43(6.8)$ & $590(93.2)$ & \\
\hline Middle & 73 & $8(11.0)$ & $65(89.0)$ & \\
\hline Last & 534 & $39(7.3)$ & $495(92.7)$ & \\
\hline \multicolumn{4}{|l|}{ Chronic disease [n (\%)] } & \multirow{3}{*}{0.021} \\
\hline Yes & $64(5.2)$ & $10(15.6)$ & $54(84.4)$ & \\
\hline No & $1176(94.8)$ & $80(6.8)$ & $1096(93.2)$ & \\
\hline Total [n (\%)] & $1240(100.0)$ & $90(7.3)$ & $1150(92.7)$ & \\
\hline
\end{tabular}

\begin{tabular}{|c|c|c|c|c|}
\hline \multirow{2}{*}{ Characteristics } & \multirow{2}{*}{ Total ${ }^{a}$} & \multicolumn{2}{|c|}{ Home injury occurance } & \multirow{2}{*}{ p-value } \\
\hline & & Positive & Negative & \\
\hline \multicolumn{4}{|l|}{ Family type [n (\%)] } & \multirow{4}{*}{0.215} \\
\hline Nucleus & $1142(92.1)$ & $84(7.4)$ & $1058(92.6)$ & \\
\hline Extended family & $66(5.3)$ & $2(3.0)$ & $64(97.0)$ & \\
\hline Single parent & $32(2.6)$ & $4(12.5)$ & $28(87.5)$ & \\
\hline Number of people living at home [Mean $( \pm S D)]$ & $3.9( \pm 0.9)$ & $4.0( \pm 0.9)$ & $3.9( \pm 0.8)$ & 0.612 \\
\hline \multicolumn{4}{|l|}{ People who needs special care at home } & \multirow{3}{*}{0.657} \\
\hline Yes & $21(1.7)$ & $1(4.8)$ & $20(95.2)$ & \\
\hline No & $1219(98.3)$ & $89(7.3)$ & $1130(92.7)$ & \\
\hline \multicolumn{4}{|l|}{ Income level of the family } & \multirow{3}{*}{0.826} \\
\hline Poor & $17(1.4)$ & $1(5.9)$ & $16(94.1)$ & \\
\hline Middle and upper & $1223(98.6)$ & $89(7.3)$ & $1134(92.7)$ & \\
\hline \multicolumn{4}{|l|}{ The income-expense balance of the family } & \multirow{3}{*}{0.002} \\
\hline Income equal to expense or income more than expanse & $1138(91.8)$ & $75(6.6)$ & $1063(93.4)$ & \\
\hline Income less than expense & $102(8.2)$ & $15(14.7)$ & $87(85.3)$ & \\
\hline Mother's age [Mean $( \pm S D)]$ & $33.1( \pm 5.0)$ & $32.8( \pm 4.6)$ & $33.1( \pm 5.0)$ & 0.580 \\
\hline \multicolumn{4}{|l|}{ Educational status of mother [n (\%)] } & \multirow{3}{*}{0.286} \\
\hline High school and lower & $608(49.0)$ & $49(8.1)$ & $559(91.9)$ & \\
\hline University and higher & $632(51.0)$ & $41(6.6)$ & $591(93.4)$ & \\
\hline
\end{tabular}




\begin{tabular}{|c|c|c|c|c|}
\hline \multirow{2}{*}{ Characteristics } & \multirow{2}{*}{ Total $^{\mathrm{a}}$} & \multicolumn{2}{|c|}{ Home injury occurance } & \multirow{2}{*}{ p-value } \\
\hline & & Positive & Negative & \\
\hline \multicolumn{4}{|l|}{ The working condition of the mother [n (\%)] } & \multirow{3}{*}{0.234} \\
\hline Not working & $505(40.7)$ & $42(8.3)$ & $463(91.7)$ & \\
\hline Working & $735(59.3)$ & $48(6.5)$ & $687(93.5)$ & \\
\hline Father's age [Mean $( \pm$ SD $)]$ & $36.3( \pm 5.4)$ & $36.3( \pm 4.5)$ & $36.3( \pm 5.4)$ & 0.952 \\
\hline \multicolumn{4}{|l|}{ Educational status of father $[\mathrm{n}(\%)]$} & \multirow{3}{*}{0.503} \\
\hline High school and lower & $496(34.0)$ & $39(7.9)$ & $457(92.1)$ & \\
\hline University and higher & $744(66.0)$ & $51(6.9)$ & $693(93.1)$ & \\
\hline \multicolumn{4}{|l|}{ The working condition of the father [n (\%)] } & \multirow{3}{*}{0.882} \\
\hline Not working & $16(1.7)$ & $1(6.2)$ & $15(93.8)$ & \\
\hline Working & $1219(98.3)$ & $88(7.2)$ & $1131(92.8)$ & \\
\hline \multicolumn{4}{|l|}{ Type of house [n (\%)] } & \multirow{3}{*}{0.931} \\
\hline Apartment & $1010(81.5)$ & $73(7.2)$ & $937(92.8)$ & \\
\hline Single house & $230(18.5)$ & $17(7.4)$ & $213(92.6)$ & \\
\hline \multicolumn{4}{|l|}{ Type of house heating [n (\%)] } & \multirow{3}{*}{0.504} \\
\hline Heater & 1139 (91.9) & $81(7.1)$ & $1058(92.9)$ & \\
\hline Stove & $101(8.1)$ & $9(8.9)$ & $92(91.1)$ & \\
\hline Number of security measures taken at home $[$ Mean $( \pm S D)]$ & $15.9( \pm 2.6)$ & $15.2( \pm 2.6)$ & $16.0( \pm 2.6)$ & 0.018 \\
\hline Security measure diagnostic score $[$ Mean $( \pm S D)]$ & $174.5( \pm 15.2)$ & $171.4( \pm 16.7)$ & $174.8( \pm 15.1)$ & 0.040 \\
\hline Total [n (\%)] & $1240(100.0)$ & $90(7.3)$ & $1150(92.7)$ & \\
\hline
\end{tabular}

objects (68.7\%). 63.6\% of the children were treated in a health facility after their injury and $3.0 \%$ had permanent damage (Table III). The injuries mostly happened in the living room (25.3\%). The injuries most frequently occurred in June-July-August (38.4\%), on Tuesdays (19.2\%) and in the afternoon (47.5\%) (Table IV). The mean score of the security measures of the mothers was determined to be 174.5 \pm 15.2 (minimum: 98/maximum: 200). The safety measures score was lower in those mothers whose children who had had an injury $(p=0.040)$. It was determined that fewer safety precautions were taken in the homes of those children who had had an injury ( $p=0.018)$ (Table II). Household injuries were more frequent among children with chronic illnesses and those living in families with lower incomes ( $p=0.021$ and $p=0.002)$ (Table I and II). There was no difference in the frequency of household injuries according to variables such as age of the child, number of siblings, number of children, number of people living at home, or the age of the parents or their education (Table I and II).
The variables and analysis results that were significant in this model when the variables that were significantly related in univariate analyses (having chronic disease, low income, home prevention measure, and security measure diagnosis score) were taken into the logistic regression model are shown in Table V. It was seen that a chronic illness in the child [odds ratio $(O R)=2.68$ ] and a low income in the family $(O R=2.73)$ were found to increase the incidence of home injuries. On the other hand, a high security assessment diagnostic score of the mothers $(\mathrm{OR}=0.98)$ was found to reduce the incidence of home injuries.

\section{Discussion}

In this study, the frequency of home injuries in children over 3 years of age attending a kindergarten was determined and factors relating to these home injuries were examined. $26.4 \%$ of the children were found to have had a home injury during a period of their lives, and $7.3 \%$ were found to have had a home injury within the previous 1 year. Similarly, in a thesis study conducted by Boztaş (8) with children aged 
between 0-48 months, the incidence of injuries as a result of home injuries during their lives was reported to be $24.5 \%$. In a study conducted in a children's clinic of a university hospital, $30.2 \%$ of children in the 0-6 age group were found to have had at least one home injury (9). It is possible that

Table III. Characteristics of injuries due to home injuries in the last year in the research group

\begin{tabular}{|c|c|}
\hline Characteristics & n (\%) \\
\hline \multicolumn{2}{|l|}{ Type of injury } \\
\hline Falling from bed/sofa/furniture/tree & $25(25.3)$ \\
\hline Collision with objects & $19(19.2)$ \\
\hline Falling due to slipping/falling from the stairs & $17(17.2)$ \\
\hline $\begin{array}{l}\text { Compression, catching, crushing, pressing between } \\
\text { objects }\end{array}$ & $10(10.1)$ \\
\hline $\begin{array}{l}\text { Contact with hot liquids/household appliances/ } \\
\text { materials }\end{array}$ & $8(8.1)$ \\
\hline Contact with animals/biting & $6(6.0)$ \\
\hline Contact with sharp object & $5(5.0)$ \\
\hline Other** & $9(9.1)$ \\
\hline \multicolumn{2}{|l|}{ Injured region } \\
\hline Upper and/or lower extremity & $53(53.5)$ \\
\hline Head -neck-eye-ear-face & $40(40.5)$ \\
\hline Body-thorax-back & $3(3.0)$ \\
\hline General (poisoning-drowning) & $3(3.0)$ \\
\hline \multicolumn{2}{|l|}{ Injury-causing object } \\
\hline Household goods/blunt objects & $68(68.7)$ \\
\hline Hot objects (stove, hot water, fire) & $7(7.1)$ \\
\hline Animals & $6(6.0)$ \\
\hline Cutting/drilling tools & $6(6.0)$ \\
\hline Electric/electric tools & $2(2.0)$ \\
\hline Other & $10(10.2)$ \\
\hline \multicolumn{2}{|l|}{ Intervention in health facility after injury } \\
\hline Yes & $63(63.6)$ \\
\hline No & $36(36.4)$ \\
\hline \multicolumn{2}{|l|}{ Result after the injury } \\
\hline Full recovery & $95(96.0)$ \\
\hline Permanent damage & $3(3.0)$ \\
\hline Temporary damage & $1(1.0)$ \\
\hline Total & $99(100.0)$ \\
\hline
\end{tabular}

*In the past year, a total of 99 injuries happened including 82 children involved in one injury, 7 children involved in an injury for two times and 1 children for 3 times.

${ }^{* *}$ Contact with electrical devices/electric shock 2 times; ingestion of foreign bodies in to body cavities/skin 3 times foreign body evacuation/threats to breathing 2 times; medicine etc. biological substance poisoning 2 times some families would not remember an injury after a certain period of time. At the same time, some families might try to conceal some of their home injuries. Considering these facts, it can be thought that the frequency of home injuries in children is higher than reported (10). This is an important public health problem because of the high incidence of home injuries in children and their consequences such as permanent injury or even death. One of the most important

Table IV. In the research group, space and time characteristics of the home injuries in the last year

\begin{tabular}{|l|l|}
\hline Characteristics & n (\%) \\
\hline \multicolumn{2}{|l|}{ The place where the injury happened } \\
\hline Lounge & $25(25.4)$ \\
\hline Living room & $14(14.1)$ \\
\hline Children room & $14(14.1)$ \\
\hline Kitchen & $14(14.1)$ \\
\hline Garden & $8(8.1)$ \\
\hline Master bedroom & $7(7.1)$ \\
\hline Entree & $7(7.1)$ \\
\hline Apartment vacancy, stairs, elevator & $5(5.0)$ \\
\hline Balcony, roof & $3(3.0)$ \\
\hline Bathroom & $1(1.0)$ \\
\hline Toilet & $1(1.0)$ \\
\hline
\end{tabular}

The month of the injury

\begin{tabular}{|l|l|}
\hline December-January-February & $19(19.2)$ \\
\hline March-April-May & $24(24.2)$ \\
\hline June-July-August & $38(38.4)$ \\
\hline September-October-November & $18(18.2)$
\end{tabular}

The day of the injury

\begin{tabular}{|l|l|}
\hline Tuesday & $19(19.2)$ \\
\hline Monday & $18(18.2)$ \\
\hline Friday & $16(16.2)$ \\
\hline Wednesday & $15(15.2)$ \\
\hline Saturday & $12(12.1)$ \\
\hline Sunday & $12(12.1)$ \\
\hline Thursday & $7(7.0)$
\end{tabular}

Time period of the injury

\begin{tabular}{|l|l|}
\hline Afternoon & $47(47.5)$ \\
\hline Evening & $27(27.3)$ \\
\hline Morning & $23(23.2)$ \\
\hline Night & $2(2.0)$ \\
\hline Total & $\mathbf{9 9 ( 1 0 0 . 0 )}$ \\
\hline
\end{tabular}




\begin{tabular}{|c|c|c|}
\hline Variable * & $\begin{array}{l}\text { OR } \\
\text { ( } 95 \% \text { confidence } \\
\text { interval) }\end{array}$ & p-value \\
\hline $\begin{array}{l}\text { Presence of Chronic Disease in } \\
\text { Child }\end{array}$ & $2.68(1.30-5.51)$ & 0.007 \\
\hline Lower income of family & $2.73(1.49-4.99)$ & 0.001 \\
\hline $\begin{array}{l}\text { Security Prevention Diagnostic } \\
\text { Score }\end{array}$ & $0.98(0.97-0.99)$ & 0.029 \\
\hline Hoshmer-Lemeshow Test & & 0.672 \\
\hline \multicolumn{3}{|c|}{$\begin{array}{l}\text { OR: Odds ratio (Estimated Relative Risk) } \\
\text { *In the Logistic regression analysis Backward-LR method; "Number of Security } \\
\text { Measures to be taken at Home" is excluded from the model. }\end{array}$} \\
\hline
\end{tabular}

reasons for the frequent occurrence of home injuries is that these injuries are unpredictable. Many of these injuries happen in situations where risky behaviour is not foreseen by families (11). Another reason is that children have to live in an environment which was designated for adults (12). Designing children's environments according to the needs of children and taking precautions against injuries will significantly reduce the risk of home injuries.

In this study, it was determined that the two most common home injury types were falling and collision with objects respectively within the previous year. In a thesis study conducted by Gündüz and Aytekin (13), it was found that the most common causes of home injuries were falling (55.0\%) and collision with objects (15.2\%). In a study by Özmen et al. (14), it was found that falling was the most common type of home injury. This may be due to the fact that this age group is not yet aware of the danger, their muscular coordination has not yet reached a sufficient level, they have increased mobility and there is a lack of supervision by their parents.

In this study, it was determined that the most commonly injured area in children was the upper and/or lower extremity. As the most common home study accident is falling, extremity injuries can be seen more frequently. This result is compatible with other studies in the literature. In a survey conducted by Kılıç et al. (15), it was found that the most frequently injured body areas were hands, arms and fingers (55\%), and legs and feet $(27 \%)$ were second. In a study conducted by Sütoluk et al. (16), it was reported that the most common injury type was the upper extremity injuries.

In this study, it was determined that children had injuries the most frequently in the living room. In most of the studies in the literature, the most common location of accidents at home was identified as the living room $(9,13,17)$.
This can be thought to be due to the fact that families spend most of their time in the living room, and that children use this part of the house as a playground.

In this study, home injuries were found to occur most frequently in summer. It is reported in the literature that injuries related to home injuries occur more frequently in spring and summer (18). This may be due to increased movement of children because of increased air temperatures and associated increased movements.

In this survey, it was found that home injuries most frequently occur on Tuesday. A study by Şahiner et al. (19) found that home injuries are most common on Monday. It is thought that injuries happen more often as a result of the parents being more tired after the first working day of the week and thus supervising their children less.

In this study, it was determined that home injuries were seen more frequently in the afternoon. This may be due to the fact that this part of the day is play-time for children. This result is similar to other studies in the literature. Boztaş's study (8) reported that home injuries occur most frequently between 12.00 and 19.00 hours. In a thesis study conducted by Yıldırım (20), it was found that children aged between 1-4 years had home injuries most frequently in the afternoon.

In this study, it was determined that the presence of a chronic disease in the child in multiple analyses was one of the determinants in the increasing incidence of home injuries. Children with health problems can be considered to have a higher risk of injury because they are more sensitive. Boztaş's study (8) found that children who had health problems experienced twice as many home injuries in a twoweek period when compared to children who did not have any health problems. In this study, it was determined that, in multiple analyses, a lower family income is a determinant in the increase in the frequency of home injuries. In other studies in the literature, it was stated that the children of families with low socio-economic levels have more home injuries $(10,21,22)$. This may be due to the fact that families with low economic levels have poor housing. The priorities of spending may differ due to the inadequate economic situations of these families. As a result, the necessary arrangements may not have been made to prevent injuries at home.

In this study, it was determined that in multivariate analyses, high scores on the safety measures of the mothers were determinants in reducing the incidence of home injuries. In other studies in the literature, it was reported that children who had had home injuries had a lower score 
in the diagnosis of security measures by their mothers $(10,13)$. This age group of children are not conscious of protecting themselves against injury. For this reason, it is very important for the mothers to create safe environments for their children and to remove any dangerous objects or keep their children away from dangerous situations.

In this study, it was found that although there was not a decisive factor in the multivariate analysis of the lower security measures taken at home by some families, fewer safety measures had been taken in the homes of children who had had a home injury in univariate analyses. An unsafe home environment plays an important role in the occurrence of home injuries. Home injuries are preventable events when injuries are predicted by identifying risk factors at home. A study by Balibey et al. (23) reported a significant positive correlation between the home unsafety score and home injuries per child.

\section{Study Limitations}

In this study, due to the memory factor, it is possible that parents might not have remembered or not fully remember home injuries which had happened to their children. The findings from this study are specific to the city where the study was conducted and differences may be seen with other cities or across the country. This cross-sectional study has limitations. As the cause and the result were evaluated at the same time, it is difficult to say that the factor lead to the result.

\section{Conclusion}

It is important for healthy societies to be protected against risks and for individuals to be in a healthy environment throughout their childhood. Injuries are an important problem which affects all of the people in a society and these preventable events can occur frequently during childhood, having negative health effects by causing physical and psychological problems.

In this study, it was found that one in four children had had a home injury at one time in their lives, the most common home injury type being falling, and the most frequently injured area was the upper and/or lower extremity. It was determined that injuries occurred most commonly in the living room, during the summer months, on Tuesdays and in the afternoon. Those with chronic illnesses, those with lower family income, and those with lower scores on the identification of security measures by their mothers were found to have more frequent domestic injuries.
Children in this age group are very inquisitive. Parental supervision of their children is very important as a means of prevention from possible injuries. It should not be forgotten that home injuries are not a matter of bad luck and they can be avoided if measures are taken. In order to determine the precautions to be taken, parents should make observations in the house and in the garden by going down to the eye level of the child. As a result, possible hazards can be determined and eliminated. Children should be informed about the conditions they should be careful about and the actions that should not be done, and they should be informed about the results of their negative behaviour. Particularly, awareness studies should be carried out for mothers and other child carers regarding home injuries.

\section{Ethics}

Ethics Committee Approval: Required permissions for the study was obtained from the Ethics Committee of the Süleyman Demirel University Faculty of Medicine (Decision no: 200).

Informed Consent: Informed consent was obtained from the participants.

Peer-review: Internally peer-reviewed.

\section{Authorship Contributions}

Design: E.U., S.Y., M.V.Y., A.Ç., Y.T., Data Collection or Processing: E.U., S.Y., M.V.Y., A.Ç., Y.T., Analysis or Interpretation: E.U., S.Y., M.V.Y., A.Ç., Y.T., Writing: E.U., S.Y., M.V.Y., A.Ç., Y.T.

Conflict of Interest: The authors declared no conflict of interest.

Financial Disclosure: The authors declared that this study received no financial support.

\section{References}

1. Özcebe H. Kazalar ve Illk Yardım. İçinde: Güler Ç, Akın L (ed). Ankara, Halk Sağlığı Temel Bilgiler Hacettepe Üniversitesi Yayınları, 2006.

2. World Health Organization [WHO]. (2005). Preventing Children Accidents and Improving Home Safety In The European Region. Identifying Means To Make Dwellings Safer. Report of a WHO expert meeting, Bonn May 30-31 2005. Retrieved 05/01/2021, from http://www.euro.who.int/ data/assets/ pdf_file/0008/98666/Bonn_accident_rep.pdf

3. Bertan M, Çakır B. Halk Sağlığı Yönünden Kazalar. İçinde: Bertan M, Güler Ç (ed). Halk Sağlığı Temel Bilgiler Kitabı. Ankara, Güneş Kitabevi Yayınları, 1997.

4. Erkal S, Şafak Ş. Tuzluçayır Sağlık Ocağı Bölgesinde Yaşayan Ailelerde Ev Kazası Görülme Durumu ve Konutların Ev Kazası Riski Açısından İncelenmesi. Sağlık ve Toplum 2003; 96-100. 
5. Çınar ND. 0-6 Yaş Grubu Çocukların Ev Kazalarından Korunmasında Ailenin Rolü. Klinik Çocuk Forumu 2004; 62-6.

6. Çınar NS, Görak G. Validity and reliability study of the development of the scale to identification safety measures for mothers' home accidents in 0-6 years old children. Çocuk Forumu Dergisi 2003; 6:22-7.

7. World Health Organization [WHO]. International Statistical Classification of Diseases and Related Health Problems 10th Revision (ICD-10) Version for 2010 Retrieved 05/01/2021, from http://apps.who.int/classifications/icd10/browse/2010/en\#/ XIX

8. Boztas G. Identification of Children 0-48 Months of Home Injuries Affecting Results of mothers and their views on the behavior of the resulting injury Factor. Thesis, Hacettepe University Faculty of Medicine, Department of Public Health, Ankara, 2008.

9. Şekerci E, İnal S. Investigation of Home Accidents Knowledge and Practices of Mothers of 0-6 Age Group Inpatient Children. HSP 2016; 3:160-72.

10. Karatepe TU, Akış N. The Frequency of Having Home Accident Among 0-6 Aged Children and Related Factors. Journal of Uludag University School of Medicine 2013; 39:165-8.

11. Öntürk ZK, Balcı S. Childhood injuries: Creating safe home environment. Cumhuriyet Nurs I 2015; 4:41-7.

12. WHO. Child and Adolescent Injury Prevention: A WHO Plan of Action 2006-2015. Geneva, 2006. Retrieved 05/01/2021, from http://apps.who.int/iris/ bitstream/10665/43267/1/9241593385 eng.pdf

13. Gündüz G, Aytekin A. Attitudes of Mothers Towards Protecting Their Children From Home Accidents and the Affecting Factors. Behcet Uz Cocuk Hast Derg 2015; 5:184-92.

14. Özmen D, Ergin D, Şen N, Çetinkaya AÇ. Tr: 0-6 Yaş Grubu Çocuğu Olan Annelerin Ev Kazalarına Yönelik Güvenlik Önlemlerinin Tanılanması. Eng: To identify safety measures of mothers of children aged between 0 and 6 years against home accidents. Aile ve Toplum 2007; 3:13-20.
15. Kılıç B, Demiral Y, Özdemir Ç, et al. Incidence of Home Injuries in a Slum Settlement District in İzmir. Toplum Hekimliği Bülteni $2006 ; 25: 27-32$.

16. Sütoluk Z, Savaş $N$, Demirhindi $H$, Özdener $N$, Akbaba $M$. Etiological and Demographic Characteristics of Domestic Accidents at the Adult Emergency Department of Faculty of Medicine, Cukurova University. Toplum Hekimliği Bülteni 2007; 26:29-33.

17. Alasya E. The Incidence of Home Accidents Among Children Aged 1-6 Years and the Practices of Mothers Related With Home Accidents. Near East University, Institute of Health Science Nursing Program, Master's Thesis, Lefkoşa, 2012.

18. Baysal SU, Yıldırım F, Bulut A. Çocuk Güvenliği Yaralanmalardan ve Zehirlenmelerden Korunma Güvenlik Kontrol Listesi. İstanbul, İstanbul Tıp Fakültesi Basımevi, 2005.

19. Şahiner P, Özkan Ö, Hamzaoğlu O. The incidence and risk factors of the home accidents in the househoulds with low socioeconomic level in Kocaeli. TAF Prev Med Bull 2011; 10:25768.

20. Yıldırım N. The determination of risks factors for home accidents among children in the one to four years old period and the effectiveness of nursing interventions based on social learning theory on decreasing these risk factors. (Doctorate Thesis), Hacettepe University, Institute of Health Sciences, Program of Public Health Nursing, Ankara, 2010.

21. Kendrick D, Young B, Mason-Jones AJ, et al. Home Safety Education and Provision of Safety Equipment For İnjury Prevention. Cochrane Database Syst Rev 2007; CD005014.

22. Schwebel DC, Gaines ). Pediatric Unintentional İnjury: Behavioral Risk Factors and İmplications for Prevention. J Dev Behav Pediatr 2007; 28:245-54.

23. Balibey M, Polat S, Ertem I, Beyazova U, Şahin F. Factors causing home accidents in childhood. STED 2011; 20:89-97. 